\title{
International Journal of Multicultural
} and Multireligious Understanding

\section{The Effect of Halal Destination Image, Travel Motivation and Marine Tourism as Branding Icons on Tourists' Decisions to Revisit}

\author{
Noni Antika Khairunnisah ${ }^{1}$; Sulhaini ${ }^{2}$; Lalu Edy Herman Mulyono ${ }^{2}$ \\ ${ }^{1}$ Mahasiswa Magister Manajemen, Universitas Mataram, West Nusa Tenggara, Indonesia \\ ${ }^{2}$ Management Department, Universitas Mataram, West Nusa Tenggara, Indonesia \\ http://dx.doi.org/10.18415/ijmmu.v7i11.2119
}

\begin{abstract}
This research aims to investigate the influence of the Halal Destination Image, Travel Motivation, and marine tourism as branding icons on the decision to return. The sample was determined by purposive sampling with the criteria of tourists visiting Tanjung Aan Beach, who were included in the millennial generation with a minimum of one visit. This research uses of quantitative approach with a sample of seventy-five respondents. Data analysis used Statistical Product and Service Solution (SPSS) Version 16. The results of this research showed that the Halal Destination Image variable had a negative and insignificant effect on the decision to revisit tourists, the Travel motivation variable has a positive and significant influence on the decision to revisit tourists, and the marine tourism variable as a branding icon has a positive and significant effect on the decision to revisit tourists. This research is expected to be a reference, especially for the government and stakeholders in optimizing the implementation of the Halal Destination Image in a better direction, as well as increasing the decision to visit tourists to visit Tanjung Aan Beach tourism.
\end{abstract}

Keywords: Halal Destination Image; Travel Motivation; Icon Branding; Decision to Revisit

\section{Introduction}

The tourism sector has many benefits in the economy, especially the free trade market, to positively impact the country's economic prosperity and availability of employment opportunities. Tourism can provide a very large contribution to income, such as the wealth and power contained in the micro economy so that economic turnover is centered not only on the urban environment (Prasaliani, 2019). Tourism constitutes a sector that is able to withstand the global crisis when viewed from the progress of world tourism, which has experienced significant development since 1950 with the number of tourist trips achieved 25 million people, in 1980 it achieved 278 million people, in 1995 achieved 528 million people and 1.1. billion people in 2014 (Ratman, 2016). According to the 2017 Global Muslim Travel Index (GTMI) produced by MasterCard and crescent, a halal tourism consultancy explains that a growing market segment can be seen from the potential expenditure of Muslim tourists is expected to 
increase to US 220 billion in 2020. With the number of Muslim tourists increasing to 156 million, which previously only reached 121 million in 2016 (Belopilskaya, 2020).

Millennial Muslims are a generation of digital technology users, so they can utilize technology to search destination halal holidays through various e-commerce or Online Agents (OTA), which are currently starting to emerge. Then, when viewed in terms of expenditure, the millennial Muslims are the group that has ready to pay more to travel. Apart from traveling two until five times every year, traveling for them is not just for traveling, but is often regarded as an opportunity for self-development, looking for superior experiences compared to others (Prodjo, 2017). Millennial tourists are becoming a very interesting phenomenon, and this generation is formed with a pup culture lifestyle (Alvianna \& Alvianna, 2020) supported by very rapid technological developments, all kinds of information are easily obtained, and the development of social media is very easy for tourists to determine or choose a destination to be addressed. This is inseparable from the current generation, usually called the millennial generation, which is able to adapt and access existing technological developments.

According to (GMTI, 2016). The development of halal destinations in Indonesia, especially to Lombok Island, contributes to rapid economic growth. Furthermore, Indonesia is one of the ten countries with the highest score, results of the current data obtained from the Global Muslim Travel Index (GMTI) in 2019, Indonesia is designated as a halal tourism destination. The first rank after Malaysia. Based on Indonesia's halal tourism results, four criteria are considered basic references, Access, Communication, Environment, and Service (ACES).

Previous research has researched a lot of travel motivation and marine tourism as branding icons. However, research on the halal destination image is still very limited. There is no researcher conducted jointly on the halal destination image, travel motivation, and marine tourism as branding icons. So that in this research, the researchers raised a gap by investigating through management analysis regarding the influence of the halal destination image, travel motivation, and marine tourism as branding icons on the decision to revisit tourists on Tanjung Aan Beach.

\section{Literature Review}

\section{a. Destination Image}

According to (Abdullah et al. 2013), identifying the factors (five cs), mixed Islamic marketing. The first commitment emphasizes instilling assurance in business transactions via marketing activities that can be trusted by applying Islamic principles. The second, characters describe Islamic marketing's distinctive character, which can be seen in product design, specifications, and promotions, which are by Islamic principles. The third, Conformity depends on compliance in terms of the processes involved in creating and delivering Islamic products/services. The fourth, conscience, is related to Islamic marketing's ethical dimension, which emphasizes the true meaning of promotion and price clarity by Islamic teachings. The five, customer-centric describes as a customer approach; this is mainly related to marketing in general.

\section{b. Travel Motivation}

According to (Suherlan, 2014) said that a person's travel motivation is influenced by internal factors of the tourists themselves and external factors. Intrinsically, motivation is formed because of human need or desire. According to (Holloway \& Humphreys, 2019), classifying travel motivation into two types, general motivation is shown to achieve broad goals, such as moving away from routine and pressure at work to enjoy a different and healthy environment. Second, there is a special motivation, 
which is a show to achieve more specific goals such as taking a walk in the fresh air and enjoying the varied view.

\section{c. Maritime Tourism as Icon Branding}

In coastal areas, tourism can be developed by attention to conservation aspects, it is ecotourism: nothing damage resources refer to the environment, education, understanding by various parties, and must provide long-term benefits in all aspects and protected marine areas. A brand identifies a seller or manufacturer of a product or service. According to (Kolter, 2005) Explaining a Brand is a complex symbol that can convey up to six levels of understanding as follows:

a. Attribute: a brand can remind of certain attributes.

b. Benefit: attributes should be translated to functional and emotional benefits, a brand also says something about its producer value.

c. Culture: a brand maybe symbolize a particular culture

d. Personality: a brand can reflect a certain personality.

e. User: a brand implies the type of consumer who buys or uses a product.

\section{d. Decision to Revisit}

The concept of a return visit decision includes 4 main dimensions based on the explanation from (Kolter, 2005): 1) product, brand, 2) distributor, 3) total buyer and 4) time of purchase. These dimensions can be used to measure visiting decisions, including the selection of 1) product or service, 2) time to visit, 3) brands, and 4) number of visits made. According to (Hasibuan, 2018), defining the decision to revisit is a person's mental state that reflects a plan to take several actions within a certain time period. According to (Baharta, 2019) revisit intention is broadly defined as tourism activities experienced by tourists. Has three dimensions of revisit intention:

1) Visit again

2) Plan to Visit

3) Wish to visit

According to (Kotler \& Philip, 2009), tourists in deciding to visit a tourism destination include 6 basic elements, namely selection: product or service, distributor, brand, amount of visits, time of visit, and payment method.

\section{The Relationship Between Variables}

\section{Relationship Between Halal Destination Image to Decision to Revisit}

According to (Al-Ansi \& Han, 2019) Saying the results of his research expand current knowledge about the attributes that significantly affect the quality of halal tourism products and services offered at tourist destinations by using multi-dimensional construction in performances of halal tourist destinations. There are six aspects used in halal tourist destinations in halal-friendly destinations including food, social environment, facilities, places, information and services and clothing. Of the six aspects used as the measured dimensions there are also those that need to be considered as one of the important values felt by tourists, especially Muslim tourists, for example the quality of halal food, hotels, restaurants, shopping centers, cleanliness. So that it will help tourists increase the enjoyment and satisfaction of spending more time, money or the intention of revisit. According to (Jeong \& Holland, 2012), the power of halal destination image's influence on the decision to revisit, there are four categories used; professional advice, word of mounth, advertisement, and news. Then the higher the great halal destination image, the stronger 
the influence of tourists' decision to revisit. From the results of the above research, the researcher concluded that with the influence of the halal destination image seen from the aspect of halal food, the quality of halal certified restaurants and hotels as well as adequate worship facilities can provide satisfaction for tourists; so that came the desire to make a revisit to Tanjung Aan Beach. Based on the research results above, this study proposes the following hypothesis:

$H_{1}=$ The better the effect of the halal destination image, the stronger the decision to revisit

\section{Relationship Between Travel Motivation to Decision to Revisit}

The influence of tourist motivation on the decision to visit gets an assessment as big as the results after interpretation there is a positive relationship between tourist motivation and the decision to visit. Getting a positive assessment is the result of the manager's attention to tourists who make tourist visits. This is in accordance with the statement (Ramdani, 2019) explaining "the need in determining a tourist area must take into account consumer behavior with the state of tourism products, tourist facilities, state of tourist attractions and progress in accessibility as a support to meet tourist needs". According to Su et al (2020), it explains that travel motivation has a significant influence on visitor involvement, visitor experience and destination image which ultimately provides satisfaction for tourists to visit. According to (Swanson \& Horridge, 2006) show that travel motivation influences products or attributes that provide knowledge about tourist motivation in providing an attractive product or attribute. Based on the research above, the following hypothesis is proposed:

\section{$\mathrm{H}_{2}=$ The better the effect of the travel motivation, the stronger the decision to revisit.}

\section{Relationship Between Maritime Tourism as Icon Branding to Decision to Revisit}

According to (Gautama \& Oka, 2011), the factors that attract tourists to carry out maritime tourism activities are the hospitality factor and the service factor, which can attract the motivation or attention of tourists to make visits on maritime tourism. Furthermore, what can attract the attention of tourists to carry out maritime tourism activities is the condition of the beach and the beauty of the scenery that plays an important role to attract the attention of tourists to make return visits on maritime tourism. The results of the research referenced by (Alvianna, Patalo, \& Hidayatullah, 2020) in terms of the attractiveness and activity of maritime tourism have an influence on the decision to visit tourists. From the results of these studies, it is seen from the aspect of the role of government and management that the presence of marine tourism as a branding icon will have a good influence on tourists making return visits to Tanjung Aan Beach tourist destinations. Based on the above research results, this researcher proposes the following hypothesis:

$\mathrm{H}_{3}=$ The better the maritime tourism effect as icon branding, the stronger the decision to revisit.

\section{Method}

This type of research is a causality association research with a causality approach having a population, namely tourists who have or have returned to Tanjung Aan Beach. This study's sampling technique used non-probability sampling with the type of sampling, namely purposive screening with sample criteria including domestic tourists and Muslim tourists born in 2020 - 1980 or belonging to the millennial generation. The research site is on Tanjung Aan Beach, Central Lombok. The amount of samples used in this study was 75 people. 
Table. 1. Respondent Characteristics

\begin{tabular}{|c|c|c|}
\hline Characteristics & Frequency & Percentage (\%) \\
\hline \multicolumn{3}{|l|}{ Sex } \\
\hline Male & 35 & $48.7 \%$ \\
\hline Female & 40 & $51.3 \%$ \\
\hline Total & 75 & $100 \%$ \\
\hline \multirow{4}{*}{ Age } & 7 & $8.8 \%$ \\
\hline & 26 & $36.2 \%$ \\
\hline & 33 & $42.5 \%$ \\
\hline & 9 & $12.5 \%$ \\
\hline Total & 75 & $100 \%$ \\
\hline \multicolumn{3}{|l|}{ Education } \\
\hline SMA & 7 & $9 \%$ \\
\hline D-III & 3 & $3.8 \%$ \\
\hline S1 & 22 & $28.2 \%$ \\
\hline S2 & 34 & $47.4 \%$ \\
\hline S3 & 9 & $11.5 \%$ \\
\hline Total & 75 & $100 \%$ \\
\hline \multicolumn{3}{|l|}{ Profession } \\
\hline Student & 8 & $10.67 \%$ \\
\hline Military/Police & - & - \\
\hline Lecture & 44 & $58.67 \%$ \\
\hline Teacher & 11 & $14.67 \%$ \\
\hline Entrepreneur & 12 & $16.00 \%$ \\
\hline Total & 75 & $100 \%$ \\
\hline \multicolumn{3}{|l|}{ Visitor } \\
\hline One time & 19 & $24.4 \%$ \\
\hline Twice & 19 & $24.4 \%$ \\
\hline Three times & 27 & $34.6 \%$ \\
\hline Four time & 10 & $13.33 \%$ \\
\hline Total & 75 & $100 \%$ \\
\hline \multicolumn{3}{|l|}{ Outlay } \\
\hline $100.000-300.000$ & 46 & $59 \%$ \\
\hline $300.000-400.000$ & 1 & $1.3 \%$ \\
\hline $400.000-600.000$ & 19 & $28.2 \%$ \\
\hline$<600.000$ & 9 & 11.5 \\
\hline Total & 75 & $100 \%$ \\
\hline
\end{tabular}

\section{Instrument Validity Test and Reliability}

The indicator for the halal destination image variable according to (Nugroho \& Suteja, 2019), halal accommodation, availability of food and drinks with guaranteed items and Muslim worship facilities. The variable travel motivation refers to (Pizam, Neumann, \& Reichel,1979)physical motivation, social interaction motivation, and relaxation filling. As a branding icon, the maritime tourism variable refers to (Papageorgiou, 2016), environmental conditions, natural scenery, and tourist locations. The variable for the decision to visit again is referred to in (Grewal et al. 2008), the desire to consume the product, the plan to consume the product in the future and the need for product consumption. The validity test is used to determine whether the questionnaire is distributed or not.The questionnaire is said to be valid if it is able to prove the value of the variables studied are halal destination image, travel motivation, and marine tourism as branding icons of the decision to visit again. The validity test in this study used 
SPSS version 16 For Windows by calculating the value of $r$. item validity is determined if $r 1$ account is greater than $r 1$ table and vice versa. If the value of the $r$ account is less than $r$ table, the item is declared invalid. Test the validity and reliability of each table below:

\section{a. Instrument Validity Test}

Table. 2. Instrument Validity Test

\begin{tabular}{|c|c|c|}
\hline \\
\hline Statement of Halal Destination Image Variables & $\begin{array}{c}\text { Correlation } \\
(\mathbf{r})\end{array}$ & Explanation \\
\hline Complete worship facilities make me feel happy traveling on Tanjung Aan beach & 0.766 & Valid \\
\hline $\begin{array}{l}\text { Tanjung Aan beach tourism destination managers are very swift in dealing directly } \\
\text { with tourists' complaints }\end{array}$ & 0.668 & Valid \\
\hline Tanjung Aan beach has provided restaurants that are halal certified & 0.834 & Valid \\
\hline Traveling on Tanjung aan beach makes me relax & 0.728 & Valid \\
\hline I got a cheap price when traveling to Tanjung aan beach & 0.529 & Valid \\
\hline I feel comfortable traveling on Tanjung aan beach & 0.729 & Valid \\
\hline $\begin{array}{l}\text { I am happy with the manager of Tanjung Aan beach tourist destination who is very } \\
\text { friendly }\end{array}$ & 0.694 & Valid \\
\hline Tourists who travel to Tanjung aan beach destinations are welcomed with joy & 0.810 & Valid \\
\hline \multicolumn{3}{|l|}{ Travel Motivation Variable Statement } \\
\hline Traveling to Tanjung Aan beach makes me feel free from the burden & 0.547 & Valid \\
\hline I recommend to friends to travel to Tanjung Aan beach & 0.584 & Valid \\
\hline $\begin{array}{l}\text { Tanjung Aan beach is one of the tourist attractions that became my choice for } \\
\text { traveling }\end{array}$ & 0.652 & Valid \\
\hline Supporting Tanjung aan beach facilities and infrastructure & 0.736 & Valid \\
\hline I am very excited about traveling to Tanjung Aan beach destinations & 0.727 & Valid \\
\hline Tanjung Aan beach is one of my family's favorite tourist destinations & 0.607 & Valid \\
\hline I traveled on the cape coast to get pleasure & 0.699 & Valid \\
\hline If I travel to Tanjung Aan beach destinations, it makes me feel satisfied & 0.732 & Valid \\
\hline I feel free while traveling on Tanjung Aan beach & 0.535 & Valid \\
\hline $\begin{array}{l}\text { I want to capture tourist moments on Tanjung Aan beach through social media } \\
\text { accounts }\end{array}$ & 0.522 & Valid \\
\hline \multicolumn{3}{|l|}{ Statement of Maritime Tourism Variables as a Branding Icon } \\
\hline I feel calm by looking at the natural panorama of Tanjung Aan beach & 0.751 & Valid \\
\hline The beautiful Tanjung Aan beach conditions make me feel satisfied & 0.743 & Valid \\
\hline I love the comfortable natural scenery of Tanjung Aan beach & 0.655 & Valid \\
\hline I feel interested in traveling on Tanjung Aan beach & 0.719 & Valid \\
\hline Tanjung Aan beach environment is very clean & 0.648 & Valid \\
\hline Tanjung Aan beach tourism transportation is very easy to access & 0.727 & Valid \\
\hline Good quality roads to Tanjung Aan beach & 0.766 & Valid \\
\hline The directions greatly helped me to Tanjung Aan beach & 0.688 & Valid \\
\hline Public transportation is available at Tanjung Aan beach & 0.746 & Valid \\
\hline \multicolumn{3}{|l|}{ Statement of the Decision Revisit } \\
\hline I do not feel bored to visit again to Tanjung Aan beach & 0.744 & Valid \\
\hline I will invite my relatives to travel to Tanjung Aan beach & 0.823 & Valid \\
\hline An interesting travel experience made me return to Tanjung Aan beach & 0.836 & Valid \\
\hline I love to visit again to Tanjung Aan beach & 0.780 & Valid \\
\hline I do not feel bored to visit again to Tanjung Aan beach & 0.719 & Valid \\
\hline Tanjung Aan beach is one of the most priority destinations for me to revisit & 0.787 & Valid \\
\hline I want to travel on Tanjung Aan beach every time & 0.769 & Valid \\
\hline Public transportation is available along Tanjung aan beach & 0.737 & Valid \\
\hline I do not feel bored to visit again to Tanjung Aan beach & 0.379 & Valid \\
\hline
\end{tabular}


Based on the table above, it can be seen that in the variable influence of halal destination image there are 8 statement items, there are 10 statement items in the influence of travel motivation and the influence variable of Marine Tourism as a Branding Icon, there are 9 statement items and the influence variable of the Revisiting Decision, there are 9 statement items that are said to be valid where are each $r_{\text {account }}>r_{\text {table }}(0.227)$ and probability value $(p)<0.000$ which means the statement items for each indicator of the halal destination image variable, travel motivation, marine tourism as a branding icon and the decision to return to visit can measure what should be measured and said to be valid.

\section{b. Reliability Instrument Test}

Table 3. Reliability Testing Results

\begin{tabular}{|l|c|c|c|}
\hline \multicolumn{1}{|c|}{ Variable } & Cranach's Alpa & Role of Thumb & Explanation \\
\hline Halal Destination Image & 0.867 & 0.70 & Reliabel \\
\hline Travel Motivation & 0.835 & 0.70 & Reliabel \\
\hline Maritime tourism as Icon Branding & 0.869 & 0.70 & Reliabel \\
\hline Decision to revisit & 0.891 & 0.70 & Reliabel \\
\hline
\end{tabular}

\section{Result and Discussion}

\section{Research Data Analysis}

To determine the influence between variables formulated in the research hypothesis, this study uses multiple linear regression analysis SPSS version 16. Based on the overall regression test results on the independent variable halal destination image, travel motivation and marine tourism as branding icons and the dependent variable visiting decisions Again, the following table shows the results of multiple linear regression tests using SPSS version 16.

Table 4. Standardized Coefficients Multiple Linear Regression Test

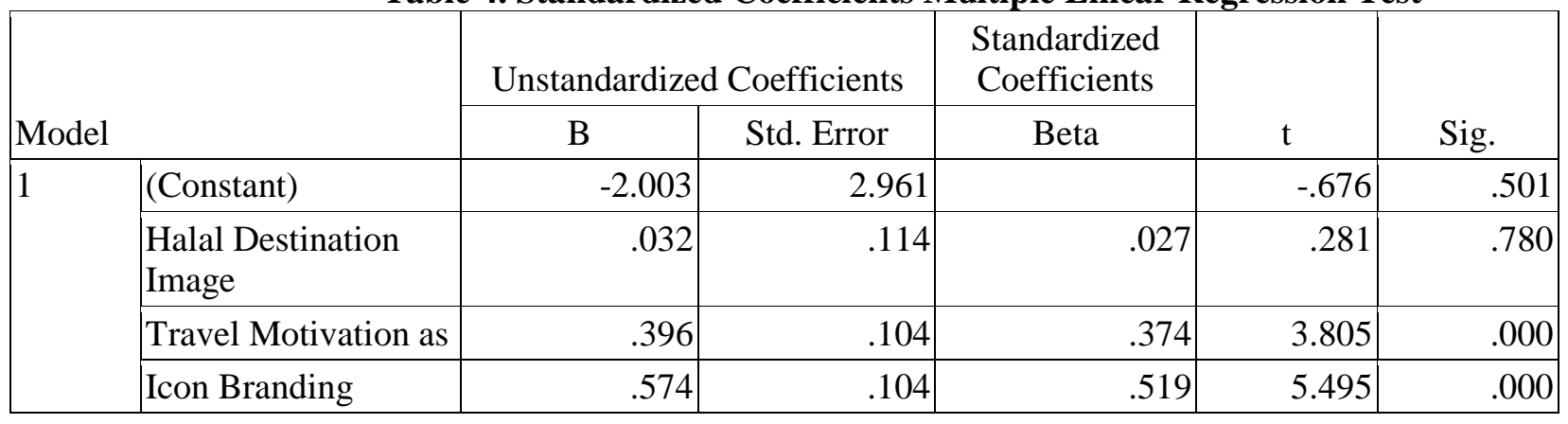

Based on the data generated in the table above, it can be explained from each coefficient using standardized coefficients, the standard coefficient for the halal destination image variable is 0.027, indicating that the weight of the influence of these variables on the decision to return to visit is 0.027 positive and insignificant. This means that if it is assumed that the halal destination image variable has increased by one point, the variable visiting decision to return will increase by the coefficient's value, provided that the other two variables have not changed. The standard coefficient for the travel motivation variable is 0.374 indicating the weight of this variable's influence on the decision to return to visit is 0.374 positive and significant. This means that if it is assumed that the travel motivation variable has increased by one point, the variable visiting decision to return will increase by the coefficient's value, provided that the other two variables have not changed. The standard coefficient for the marine tourism variable as icon branding is 0.519 , indicating that the weight of these variables' influence on the decision to visit again is 0.519 positive and significant. This means that if it is assumed that the marine tourism variable as a 
branding icon has increased by one point, the variable returning visit decision will increase by the coefficient's value, provided that the other two variables do not change.

Hypothesis testing using the SPSS version 16 for windows application can be seen in the multiple linear regression coefficients results. The results of hypothesis testing can be explained by the coefficient value and the $t$ statistical value. The results of hypothesis testing can be seen in the table as follows:

Table 5. Hypothesis Test of the Results

\begin{tabular}{|c|c|c|c|c|c|}
\hline Hypothesis & Influence Weight & t-count & Sig. & Decision & Explanation \\
\hline H1 & 0.032 & 0.281 & 0.780 & Accept Ho & Non-Significant \\
\hline H2 & 0.396 & 3.805 & 0.000 & Accept Ha & Significant $(+)$ \\
\hline H3 & 0.574 & 5.495 & 0.000 & Accept Ha & Significant $(+)$ \\
\hline
\end{tabular}

\section{Discussion}

Based on the results of the analysis using SPSS version 16 for windows, the following researchers discuss one by one the results of the calculation of the three research hypotheses that have been built and also the results of the calculation of the indirect relationship of halal destination image to the decision to return. Each discussion explains the position of this study's results with supporting literature or previous research as a contribution to knowledge. Whether this research strengthens or weakens, is in line or not in line with previous research and discusses why the relationship between these variables influences theory and results of previous research.

\section{The Effect of Halal Destination Image on the Decision to Revisit}

The effect of the halal destination image variable shows that it has a positive and insignificant effect on the decision to revisit tourists at Tanjung Aan Beach. The better the image of halal tourism according to tourists' perception is not necessarily able to create the desire of tourists to visit again. This study's results are not in line with research (Surya, Rini, \& Setiawan, 2018), which states that there is a positive and significant effect of halal destination image on visitor loyalty. As well as not supporting research (Coban, 2012), especially indicators of general cognitive images, there are six items related to knowledge beliefs about a tourism destination, consisting of tourist attractions, basic facilities, cultural attractions, and tourism accessibility substructure, natural environment and economic factors.

\section{The Effect of Travel Motivation on the Decision to Revisit}

The influence of the travel motivation variable shows significant results on revisiting tourists at Tanjung Aan Beach. Travel motivation is an encouragement for tourists to visit a tourist spot. The high motivation of tourists to visit can create tourists' desire to return to visit at another time. This study's results support research (Coban, 2012), which confirms that this behavior is in the past, which positively assesses the image of tourism destinations, including visiting and recommending destinations related to others. As well as supporting research (Mulyani, 2018) states that visiting motivation has a positive and significant effect on visiting decisions, where if the motivation variable variable increases it will also cause an increase in visiting decisions. Based on these results, the hypothesis is accepted. The results of this study support the research (Ajzen, 1988) which states that the target of the attitude is determined as revisit behavior, which is in accordance with the intention of visiting again. The results are also in line with research (Salsabilla, 2019) which states that by going through tourist trips that are usually obtained when visiting halal tourist destinations as well as halal tourism facilities that are halal in accordance with the needs of millennial Muslims in traveling so that they can increase their intention to visit tourist destinations halal. 


\section{The Effect of Marine Tourism as a Branding Icon on the Decision to Revisit}

The maritime tourism variable's effect as a branding icon shows a significant effect on the decision to revisit tourists at Tanjung Aan Beach. The maritime tourism branding icon is able to create an attraction for tourists. A strong branding of a tourist spot can be an icon that tourists always remember. Therefore, tourists are likely to make return visits to tourism locations that really have a strong icon. This research is in line with research according to (Gautama I. A., 2011) which states that the factors attracting tourists to carry out maritime tourism activities, one of which is the hospitality factor and the service factor, which is able to attract the motivation or attention of tourists to visit maritime tourism. Furthermore, what can attract the attention of tourists to carry out maritime tourism activities is the condition of the beach and the beauty of the scenery, which plays an important role to attract the attention of tourists to make a return visit on maritime tourism.

\section{Conclusion}

The conclusions from this study's results are as follows: 1) Halal destination image has no significant positive effect on the decision to return tourists to Tanjung Aan Beach. 2) Travel motivation is positive and significant for the decision to return tourists to Tanjung Aan Beach. 3) Marine tourism as a positive and significant branding icon for the decision to revisit tourists to Tanjung Aan Beach. So it can be concluded that the variables of halal destination image, travel motivation and maritime tourism as branding icons have a significant influence on the decision to revisit tourists.

\section{References}

Abdullah, J. B., Hamali, J. H., \& Abdullah, F. (2013). "Islamic marketing mix: the critical factors. International Conference on Business an Economic Research. Vol. 4. 2013.

Ajzen, I. (1988). Attitudes, Personality and Behavior, Buckingham. England: Open Press University.

Al-Ansi, \& Han, H. (2019). Role of halal-friendly destination performances, value, satisfaction, and trust in generating destination image and loyalty. Journal of Destination Marketing \& Management, 13, 51-60.

Alvianna, S. P., \& Alvianna, S. (2020). Pengaruh Attraction, Accessibillity, Amenity, Ancillary Terhadap Kepuasan Generasi Millenial Berkunjung ke Tempat Wisata. Jurnal Kepariwisataan: Destinasi, Hospitalitas dan Perjala.

Alvianna, S. P., \& Alvianna, S. (2020). Pengaruh Attraction, Accessibillity, Amenity, Ancillary Terhadap Kepuasan Generasi Millenial Berkunjung ke Tempat Wisata. Jurnal Kepariwisataan: Destinasi, Hospitalitas dan Perjala.

Baharta, E. (2019). Jurnal Akrab Juara, 4(2), 225-240. Pengaruh Kualitas Pelayanan Terhadap Keputusan Berkunjung Kembali (Revisit Intention) Wisatawan Ke Pesona Alam Puncak. .

Belopilskaya, Y. V. (2020). How Halal Tourism Is Reshaping The Global Tourism Industry. From Https://Hospitalityinsights.Ehl.Edu/Halal-Tourism-Global-Industry.

Chang, J. C. (2007). Travel motivations of package tour travelers. . međunarodni znanstveno-stručni časopis, 55(2), 157-176.

Coban, S. (2012). The effects of the image of destination on tourist satisfaction and loyalty: The case of Cappadocia. Coban, S. (2012). The effects of the image of destination on tourist satisfaction and loyalty: The case of Cappadocia. European Journal of Social Sciences, 29(2), 222-232.

Gautama, I. G., \& Oka, G. G. (2011). Evaluasi Perkembangan Wisata Bahari di Pantai Sanur. Prog. Pascasarjana, Universitas Udayana, Denpasar.

Hasibuan, Y. J. (2018). Pengaruh Motivasi Dan Persepsi Terhadap Keputusan Wisatawan Domestik Berkunjung Kembali Ke Bukit Indah Simarjarunjung Kabupaten Simalungun.

Holloway, J. C., \& Humphreys, C. (2019). The Business Of Tourism. Sage Publications Limited. 
Hung, K., \& Petrick, J. F. (2011). Why do you cruise? Exploring the motivations for taking cruise holidays, and the construction of a cruising motivation scale.Tourism Management,32(2),386-393.

Jeong, C., \& Holland, S. (2012). Destination Image Saturation. Journal Of Travel dan Tourism Marketing, 29(6), 501-519. Doi:10.1080/10548408.2012.701162.

Kolter, p. (2005). Manajemen Pemasaran Edisi Kesebelas, Jilid 1 Edisi Bahasa Indonesia (Penerjemah Drs. Benyamin Molan Dan Bambang Sarwiji, Se). Pt. Indeks Kelompok Gramedia, Jakarta. Hal, 266-323.

Kotler, \& philip. (2009). Manajemen Pemasaran, Edisi 13. Jakarta; Erlangga.

Mulyani, A. (2018). engaruh atraksi, Motivasi Berkunjung Dan Persepsi Harga Terhadap Keputusan Berkunjung Ke Obyek Wisata Pantai Watu Bale Di Kebumen. STIE Putra Bangsa,(1), 1-14.

Nugroho, M. S., \& Suteja, I. W. (2019). Media Bina Ilmiah, 13(7), 1337-1342.

Papageorgiou, M. (2016). Coastal and marine tourism: A challenging factor in Marine Spatial Planning. . Ocean \& coastal management, 129, 44-48.

Pariwisata, K. (2012). Kemenparekraf promosikan Indonesia sebagai destinasi pariwisata syariah dunia. dalam http://www. kemenpar. go. id.

Pizam, A., Neumann, Y., \& Reichel, A. (1979). Tourist satisfaction: Uses and misuses. Annals of Tourism. Research, 6(2), 195-197.

Prasaliani, Z. M. (2019). Strategi Thailand Pada Bidang Pariwisata Dalam Kerjasama Imt-Gt (IndonesiaMalaysia-Thailand Growth Triangle). (Doctoral Dissertation,University of Muhammadiyah Malang).

Prodjo. (2017). Hitung Jumlah Wisatawan, Tiket Masuk Obyek Wisata Kebumen Dibedakan.

Ramdani, D. (2019). Pengaruh Atraksi Wisata Alam Dan Motivasi Wisatawan Terhadap Keputusan Berkunjung Wisatawan Ke Kawasan Wisata Ciwidey Dan Pangalengan. Jurnal Wacana Ekonomi, 18(1), 059-065.

Ratman, D. R. (2016). Akselerasi pembangunan kepariwisataan dalam rangka pencapaian target 12 juta wisman dan 260 juta wisnus 2016. . http.

Salsabilla, A. R. (2019). Intensi Berkunjung Muslim Milenial Ke Destinasi Wisata Halal Lombok: Analisis Destination Image, Travel Motivation, Religiusitas Dan Islamic Attributes Of Destination. (Doctoral dissertation, Universitas Pendidikan Indonesia).

Sindo, K. (2018). Prospek Wisata Halal Indonesia. Retrieved From Nasional. . Sindonews.Com:Https://Nasional.Sindonews.Com/Read/1355812/16/Prospek-WisataHalalindonesia-1542585387.

Suherlan, A. (2014). nalisis karakteristik, perilaku, dan motivasi perjalanan wisatawan asal sulawesi utara ke Jakarta. Esensi: Jurnal Bisnis dan Manajemen, 4(3).

Surya, E. D., Rini, E. S., \& Setiawan, N. (2018). The Effect of Halal Destination Image and Visitors Satisfaction on Tourist Loyalty (Object In Bukit Tinggi City Of West Sumatera). In 1st Economics and Business International Conference 2017.

Swanson, K. K., \& Horridge, P. E. (2006). Travel Motivations As Souvenir Purchase Indicators. Tourism Management, 27(4), 671-683. Doi:10.1016/J.Tourman.2005.03.001.

Wahyulina, S., Darwini, W. R., \& Oktaryani, S. (2018). Persepsi Wisatawan Muslim Terhadap Sarana Penunjang Wisata Halal Dikawasan Desa Sembalun Lawang Lombok Timur. Jmm UnramUnram Management Review, 7(1), 32-42.

\section{Copyrights}

Copyright for this article is retained by the author(s), with first publication rights granted to the journal.

This is an open-access article distributed under the terms and conditions of the Creative Commons Attribution license (http://creativecommons.org/licenses/by/4.0/). 